\begin{tabular}{|c|c|c|}
\hline Beitr. Ent. & Keltern & ISSN 0005-805X \\
\hline $55(2005) 1$ & S. $141-150$ & 01.07 .2005 \\
\hline
\end{tabular}

\title{
Thanius biennis, a new gall-inducing weevil with a two-year life-cycle from Costa Rica
}

\author{
(Coleoptera: Curculionidae: Baridinae)
}

With 30 figures

Jens Prena and Kenji Nishida

\section{Summary}

Thanius biennis Prena \& Nrshida sp. $\mathrm{n}$. is described and illustrated. The larva induced galls on stems of Psychotria marginata (Rubiaceae). The complete life-cycle took two years per generation, and two alternate generations coexisted on the same plant. Each gall harbored a single immature or adult specimen. The latter stage remained dormant in the gall for nearly five months, and emerged with the beginning of the rainy season.

\section{Zusammenfassung}

Thanius biennis Prena \& Nishida sp. n. wird beschrieben und illustriert. Die Larve verursachte Gallen an Stämmen von Psychotria marginata (Rubiaceae). Der vollständige Entwicklungszyklus dauerte zwei Jahr pro Generation, wobei zwei alternierende Generationen auf derselben Pflanze gemeinsam vorkamen. Jede Galle beherbergte ein einzelnes immatures oder adultes Tier. Letzteres Stadium verharrte nahezu fünf Monate in Ruhezustand, und schlüpfte zu Beginn der Regenzeit.

\section{Resumen}

Thanius biennis Prena \& Nishida sp. $\mathrm{n}$. es descrito e ilustrado. Las larvas se encontraron induciendo agallas en ramas de Psychotria marginata (Rubiaceae). Se duraron dos ańos para completar su ciclo de vida y dos generaciones coexisten en la misma planta. Cada agalla contiene un sólo individuo de estadio inmaduro o adulto. El adulto se quedó inactivo en la agalla por cerca de cinco meses y emergió en el principio de la época lluviosa.

\section{Key Words}

weevils, Thanius, Rubiaceae, Psychotria, galls, Calliephialtes, Neotropics 


\section{Introduction}

During a general study of gall-inducing insects in Costa Rica, the second author made observations on a baridine weevil associated with Psychotria marginata (Rubiaceae). Subsequent investigations by the first author revealed, that the specimens represent an undescribed species belonging to an ill-defined complex near Pseudobaris LECONTE. These barids are characterized by the possession of a projecting pygidium, a distinct prosternal channel, a square basal prosternal process and notably elongate aedeagal apodemes. Our species, although larger than the type species, concurs best with Thanius CASEY (1922). Champion (1908) described four related Middle American species and assigned them to Madarus SCHÖNHerR, i.e. M. astutus, M. scaphiformis, M. tremulus and M. vitiosus. However, those species bridge character states between. Thanius and Physoproctus LacordaIre. As we do not have sufficient data for a generic revision at this stage, we assign the new species provisionally to Thanius. It should be noted, that several species included there by BONDAR (1949) and Hustache (1951) belong elsewhere. In the present paper, we describe and illustrate the new species with its immature stages and report its interesting life history. Our results may help to procure further data through systematic studies in the field, which will be needed for a future revision of the entire group.

The study was carried out in the wake of the ALAS 4 project (NSF 2001-05) led by JoHn Longrno (Olympia, WA). Travel grants provided to the first author by the National Geographic Society (2003) and the Deutsche Forschungsgemeinschaft (2004) are gratefully acknowledged. INBio and MINAE provided logistic and administrative support. Lee Herman (New York), Steven Lingafelter (Washington D.C.), Klaus Klass (Dresden) and Hélèn Perrin (Paris) provided access to specimens. Carlos O. Morales (San José) identified the host plant. IAN D. Gavld (London) identified the parasitoid. Paul Hanson (San José) commented on the manuscript. Our cordial thanks are extended to all of them.

\section{Methods}

Observations and collections were made by the second author between July 2002 and May 2004 in the Reserva Ecológica Leonel Oviedo (9 $56^{\prime} \mathrm{N}, 84^{\circ} 03^{\prime} \mathrm{W}$ ), on the campus of the University of Costa Rica (UCR) in San Pedro, Montes de Oca, San José. The reserve is a 35 year-old secondary growth forest of approximately $0.01 \mathrm{~km}^{2}$ at $1150 \mathrm{~m}$ elevation. The site was used previously as a coffee plantation. According to HoLDRIDGE (1967), the habitat is considered to be a moist premontane tropical forest. However, today it is engulfed by the municipality of San José and isolated from natural habitats. STILES (1990) provides a short description of the plant community of the reserve.

Species of Psychotria are herbs, shrubs or small trees. The genus is spread widely throughout the Neotropics and is notably speciose, with approximately 115 species recorded from Costa Rica alone (INBio 2004). The range of Psychotria marginata extends from Belize southward to Bolivia (MOBOT 2004). In Costa Rica, the species can be found on both slopes of the Cordilleras Central and Talamanca, from sea level to approximately $1700 \mathrm{~m}$ elevation (INBio 2004). At least seven $2-3 \mathrm{~m}$ tall treelets occur at the study site, all of them being infested by the weevil reported upon here. 
Branches of the host plant having galls were placed in plastic bags, and the insects were reared at an average temperature of $23-24^{\circ} \mathrm{C}$ in the entomological laboratory of the university. Approximately fifty galls were dissected and studied under the dissecting microscope. Larvae, pupae, adults and galls were preserved in 75\% ethanol. Photographs were taken with Nikon Coolpix digital cameras and edited with Adobe Photoshop ${ }^{\circ}$. In the field, some mature galls were bagged with a fine mesh-cloth to intercept newly hatched weevils. Ribbon-markers were used to aid in the monitoring of the galls.

Measurements of length were made with an ocular micrometer in a dissecting microscope as follows: total length, from anterior margin of eye to pygidium in dorsal view; standard length, from anterior margin of pronotum to pygidium in dorsal view; pronotal length, longest dorsal extension in lateral view; elytral length, longest extension parallel to elytral suture; length of rostrum, straight distance from apex (without mandibles) to anterior margin of eye at middle of rostrum in lateral view; apical portion of rostrum, straight distance from apex (without mandibles) to point of antennal insertion in lateral view. Drawings were made using the grid of an ocular micrometer. The larval terminology follows that used by MaY (1994).

\section{Thanius biennis Prena \& NISHIDA sp. n.}

Holotype male, dissected, labeled: "COSTA RICA, San José Prov.:/ Universidad de Costa Rica,/ Reserva Leonel Oviedo,/ coll. Kenji Nishida", "from gall of/ Psychotria marginata/ Feb. 2003", "HOLOTYPE/ Thanius biennis/ Prena \& Nishida", deposited in Instituto Nacional de Biodiversidad, Santo Domingo de Heredia, Costa Rica. Paratypes: 7 males (1 very teneral), 9 females, all from same site as holotype, collected between December 2002 and May 2004, deposited in San José (UCR), Natural History Museums in Ottawa, Washington D.C., London and Paris, and in personal collections of O'Brien (Green Valey, Arizona) and Prena (Rostock).

Description of adult. Habitus: Fig. 1, total length $5.2-5.8 \mathrm{~mm}$, standard length $5.0-$ $5.4 \mathrm{~mm}(\mathrm{n}=15)$. Color: integument black with dark blue sheen. Head: retractile to posterior margin of eyes, transition between head and rostrum depressed, frontal fovea minute, of same size as punctation of head; rostrum moderately thick, subcylindrical, slightly compressed laterally in apical third, curved (Fig. 2), punctate, not costate, length of rostrum ơ o $1.04-1.07 \times(\mathrm{m}=1.06, \mathrm{n}=7)$, $\&$ \% $1.16-1.22 \mathrm{x}(\mathrm{m}=1.18, \mathrm{n}=8)$ pronotal length, length of ante-antennal portion ơ $0.58-0.60 \mathrm{x}(\mathrm{m}=0.59, \mathrm{n}=7)$, 우 우 $0.61-0.63 \mathrm{x}$ $(\mathrm{m}=0.62, \mathrm{n}=8)$ total rostral length, dorsal margin of antennal scrobe reaching rostral base well before eye. Antenna: funicular segment 2 shorter than 1, approximately as wide as long, distal segments transverse, transition to club gradual, club oval, pubescent. Pronotum: length $0.80-0.85 \times(m=0.82, \mathrm{n}=15)$ maximum width, greatest width at base, sides gradually converging in basal half, tubulate in front, base produced toward scutellum; disk smooth, finely and spaciously punctate, denser in front, coarser at base. Elytra: length 1.41-1.54x $(\mathrm{m}=1.44, \mathrm{n}=15)$ width at humeri, width $1.24-1.32 \mathrm{x}(\mathrm{m}=1.27, \mathrm{n}=15)$ maximum pronotal width, sides slightly converging in basal half, apices rounded separately, preapical callus weak, striae fine, sharply cut, indistinctly punctate, interstriae flat, with irregular row of very fine punctures, each with microscopic hair. Legs: moderately 
densely punctate, front and middle femora slightly expanded dorsoventrally, hind femora subparallel, venter slightly sulcate to receive tibia, femoral tooth absent, tibiae straight, ventrodistally with short cluster of brown hairs, mucro of fore leg of moderate size, of equal size in both sexes, premucro minute, tarsal claws of moderate size, arcuate, separate at base. Venter: punctures relatively large except on ventrites, center with light-colored setae; anterior coxae separated by their own width; basal process of prosternum distinct, truncate behind; prosternal channel moderately deep, impunctate, extending between anterior coxae, continued behind as pseudo-channel delimited by lateral protuberance (Fig. 3); pygidium slightly exposed behind elytra, transverse, punctate, not costate. Male (Fig. 4-9): body of aedeagus elongate, curved in lateral view, apex rounded narrowly, sclerotized, ventrolaterally with short hairs; aedeagal flagellum moderately thick, slightly depressed, lateral portion sclerotized, twice as long as body of aedeagus; apodemes nearly $3 x$ longer than body of aedeagus; tegmal parameres spaced widely; sternite 8 asymmetric, lateral arms equal, with membranous, parallel-sided posterior portion; sternite 9 divided medially, subtriangular, apical margin curved evenly. Female (Fig. 10-12): sternite 8 with 2 divaricating, basally sclerotized arms, distal portion of arms spatulate, membranous; hemisternite pigmented, stylus with approximately 6 moderate and several minute distal setae; spermatheca bulky, sclerotized; spermathecal duct approximately as long as vagina, not pigmented, inserted distally in bursa; bursa short, less than one-third of length of vagina. Sound-production: specific stridulatory organs absent, distal margin of last tergite with dense fringe of broad setae, apical portion of elytron ventrally with irregular microsculpture.

Description of larva. Habitus: cylindrical, slightly tapered frontally and caudally, dingy white (creamy white when preserved), first-instar translucent; largest specimen $10.2 \mathrm{~mm}$ $\times 2.5 \mathrm{~mm}$, slightly curved, widest at abdominal segment III (Fig. 13); cuticle finely asperate, setae translucent, inconspicuous. Head: whitish to very light brown, sutures and mandibles darker, epicranial ridge present; slightly wider than long (Fig. 14), sides variously rounded (frontal half parallel-sided in one specimen); frontal suture present, not pigmented, endocarina obsolete and short; stemmata absent; accessory appendage of basal antennal segment conical, $2 x$ longer than wide, 3-4 minute basal sensillae (Fig. 16); frontal setae 2, 4 and 5 long, 1 and 3 short; dorsal epicranial setae 1, 3 and 5 long, 2 and 4 short; 4 pairs of posterior epicranial sensillae; lateral epicranial setae 1 and 2 long; ventral epicranial seta 1 short, 2 moderately long; clypeus 3.5x wider than long, subconical, clypeal setae 1 and 2 short (Fig. 17); anterior margin of labrum slightly curved, 3 pairs of long labral setae, labral rods (tormae) separated, bar-shaped, curved (Fig. 17), hypopharyngeal lining with 2 pairs of short anteromedian setae, 1 pair of short and 2 pairs of moderately long anterolateral setae, 4 pairs of short median setae (Fig. 18); maxilla with palpus 2-segmented, basal segment with short seta and two sensillae, mala with 1 moderately long and 5 short ventral setae and row of 7 variously curved dorsal setae of subequal size (Fig. 19); labial palpus 2-segmented, premental sclerite little sclerotized, heart-shaped, 1 pair of long prelabial setae, postlabial seta 3 shorter than setae 1 and 2 (Fig. 19), 3-4 pairs of short ligular setae, anterodorsal derm densely covered with denticles; mandible with 2 pointed apical and 2 blunt subapical teeth, 2 setae on outer face (Fig. 20). Thorax: creamy white, nowhere sclerotized; 10 pairs of pronotal setae, 2 pleural setae of unequal size, 2 long and $4(-5)$ short pedal setae, 1 pair of short sternal seta; 
spiracle subcircular, with 2 inconspicuous, short, smooth air-tubes, atrium oval, vertical; meso- and metathorax with 1 pair of prodorsal and 3 pairs of postdorsal setae, 1 moderately long dorsolateral seta, 2 short alar setae, 1 long epipleural seta, 1 long pleural seta, 2 long and 4(-5) short pedal setae, 1 pair of short sternal setae. Abdomen: spiracles of segments I-VIII subcircular, with 2 inconspicuous, short, smooth air-tubes; segments I-VII with 5 pairs of postdorsal setae, VIII with 3 pairs; I-VIII with 1 pair of short prodorsal setae, 2 short spiracular setae, 2 epipleural setae of unequal length, 2 pleural setae of unequal length, 1 long laterosternal seta, 2 pairs of short sternal setae; segment 9 with 2 pairs dorsal, 2 pairs ventral and 2 lateral setae; anus terminal, 4-lobed. Material: 7 larvae collected from galls at type locality between July 2002 and February 2003.

Description of pupa. Habitus: $6.0 \mathrm{~mm} \times 2.6 \mathrm{~mm}$, wings fitted closely to body (Fig. 21). Head: moderately retracted, visible in dorsal view, 1 pair of setiferous tubercles on vertex; rostrum reaching middle of metasternum, 1 pair of setiferous tubercles at base, 1 pair of setae at midlength (Fig. 22). Thorax: pronotum transverse, greatest width at base, sides rounded toward front, apex tubulate, basal margin very slightly produced, base with elongate, shallow median depression, 9 pairs of setiferous tubercles (Fig. 21); mesonotum with 2 pairs of setae, scutellum distinct, elevated; metanotum sulcate medially, 1 pair of setiferous tubercles; pterotheca I with rows of tubercles on outer odd-numbered intervals, pterotheca II as long as pterotheca I; femora with 1 seta each. Abdomen: segments I-VIII with 2 pairs of setiferous tergal tubercles and 1 short pleural seta, sternite VIII with 1 pair of setiferous tubercles, sternite IX with 2 pairs of setiferous tubercles, pseudocerci absent. Material: 2 specimens collected from galls at type locality in December 2002

Epithet. The name is a Latin adjective and refers to the length of the life-cycle.

Life history. Immature and adult stages were found only in association with Psychotria marginata (Rubiaceae). Adult weevils appeared on the flowering host plant in the first half of May (1-13 May 2003; 11 May 2004). Individual monitoring of single galls in 2004 revealed, that two adults had prepared exit holes by the third week of April, subsequent to the first significant precipitation toward the end of the dry season, but did not abandon the galls at this stage. The weevils were seen feeding on the flowers (Fig. 26), but not on other parts of the host or on any other plant species nearby. Anthers appeared to be the preferred diet (Fig. 27). The number of adults encountered declined after approximately 10 days, and adults disappeared shortly after the fading of the flowers in the second half of May; they were not encountered anymore on the host until the next generation showed up one year later. Oviposition was not observed, but some 20 fresh scars were found in early May 2003 on parts of branches previously unaffected. The scars were light brown, raised dots, approximately $2-3 \mathrm{~mm}$ in diameter. Noticeable swellings, $5 \mathrm{~mm}$ long, $4 \mathrm{~mm}$ wide and $1 \mathrm{~mm}$ high, became apparent approximately two weeks later and grew to oval surface galls with barky texture. Only lignified branches were affected, while fresh green growth was unaffected. Some galls were dissected in December, toward the end of the rainy season, and in February, and revealed mid-sized, probably secondinstar larvae. Pupae were obtained from dissected galls in the beginning of December, 18 months after oviposition, where they rested without a cocoon. The first teneral adults 
were found in galls in the second half of December (Fig. 24), but these and further specimens brought in over the next months remained inactive until early (2004) or late (2003) April and did not take any food during captivity. In the field, adults emerged through circular, $3 \mathrm{~mm}$ exit holes made in the upper one-fourth of the galls between mid April and early May (Fig. 25), thus completing the two-year life-cycle. Nothing is known about the fate of the adult weevils after having left $P$. marginata. Observations made on undescribed congeners in Vara Blanca, Costa Rica suggest, that they may frequent flowering plants of other families.

Description of gall. The galls occurred primarily on $15-30 \mathrm{~mm}$ thick, lignified stems and branches in remarkable density, with up to 30 galls per $60 \mathrm{~cm}$ branch. Branches less than $6.5 \mathrm{~mm}$ thick were not affected. Mature galls attained the shape of an ovoid surface swelling approximately $18 \mathrm{~mm}$ long, $10 \mathrm{~mm}$ wide and $6 \mathrm{~mm}$ high (Fig. 25). The final size was reached in approximately one year. The outer surface of the aging gall was covered with light brown, longitudinally arranged lenticels or cracks. Each gall contained a single chamber that harbored a larva, pupa, or adult. Compacted blackish-brown fecal pellets were observed at the basal part (Fig. 29). Irregularly grown nutritive tissue, of granulose texture and whitish to translucent in color, covered the inner walls (Fig. 29, 30). We suspect that the nutritive tissue is re-growth of parenchyma cells. The mature gall-chamber measured approximately $7 \mathrm{~mm} \times 4 \mathrm{~mm}$.

Parasitoids. A larva of an ichneumonid wasp, Calliephialtes sp. (Pimplinae) was found in a mature gall on 21 January 2003, and was reared in the laboratory (1 male, deposited at UCR). The species is an idiobiont, i.e. the parent wasp renders the host immobile and inhibits its further growth by paralysis. The parasitized weevil larva was mature and close to pupation.

Distribution. Thanius biennis is known only from the Leonel Oviedo Reserve, on the campus of the University of Costa Rica in San Pedro, San José.

Discussion. The new species is remarkable for its rarity and the surprisingly long life-cycle. Adult specimens have not been collected before our monitoring of the galls commenced in the summer 2002, despite the considerable collecting effort carried out in Costa Rica. Subsequent observations of the site in general, and the host plant in particular, showed that the occurrence of the adult weevil is restricted to a small slot of time, of approximately two weeks, in the beginning of the rainy season, when the host plant blooms. The brief appearance of the adult stage alone would sufficiently explain this case of rarity. In addition, the population underwent a life-cycle of two years. We observed two subsequent, alternating populations on the same host. Their interrelationship remains unclear for the moment, because we have no proven case of deviation from the average cycle. We assume that the development of some individuals can deviate from the observed temporal pattern, perhaps under unfavorable weather conditions or at random. An exchange of individuals between local subpopulations is another plausible mechanism but rather unlikely at our study site due to its spatial isolation. Longevity of adult weevils combined with a second phase of reproduction seems the least likely explanation for the origin and presence of an alternate population. 


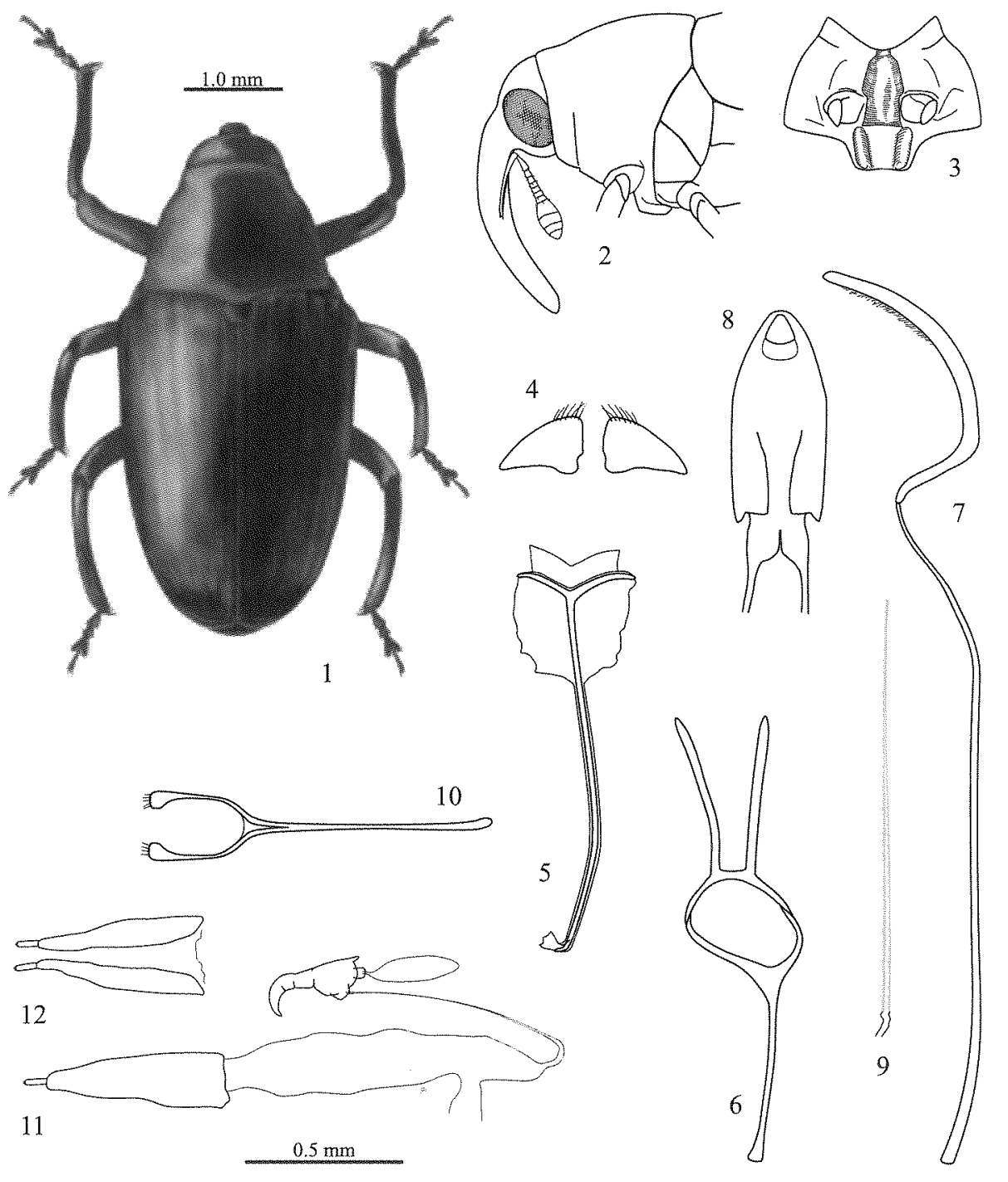

Figs. 1-12. Thanius biennis. 1, habitus, dorsal; 2 , head and prothorax, male, lateral; 3 , prosternum, ventral; 4 , male sternite 8 , ventral; 5 , male sternite 9 , ventral; 6 , tegmen; 7 , aedeagus, lateral; 8 , body of aedeagus, dorsal; 9, flagellum; 10, female sternite 8 , ventral; 11 , female genital tract; 12 , hemisternites, ventral. Genitalia scaled by factor 5 relative to habitus. 

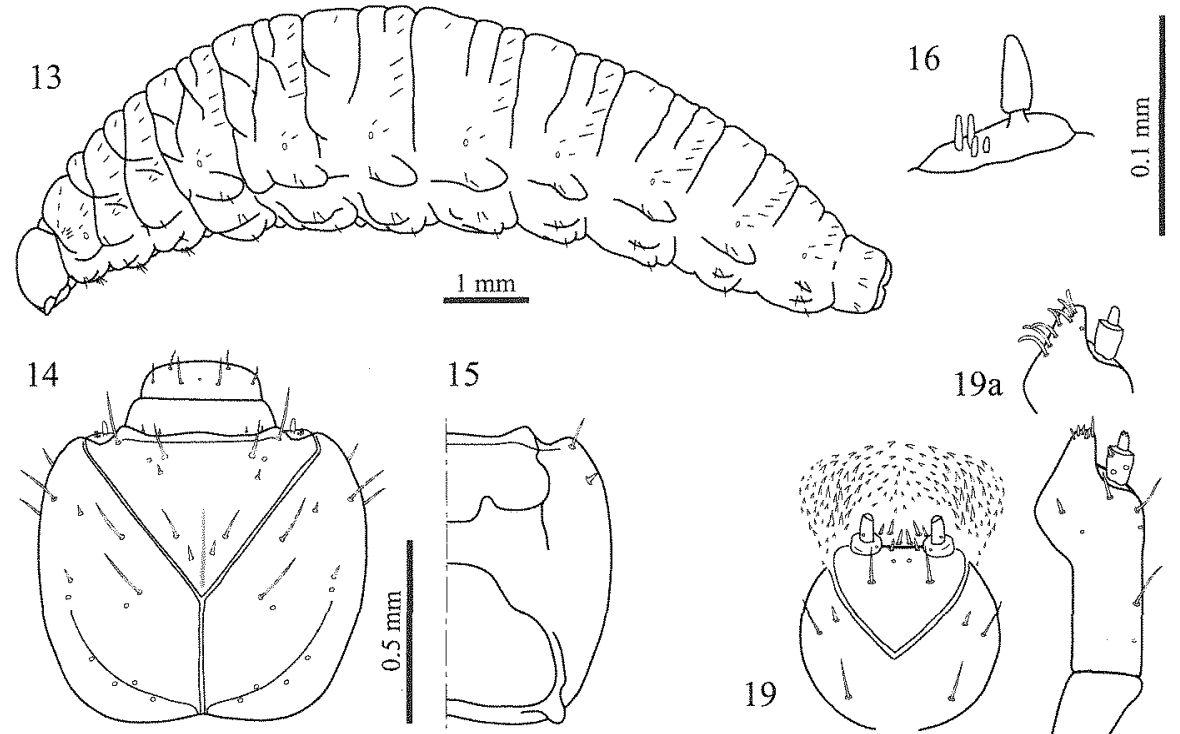

15

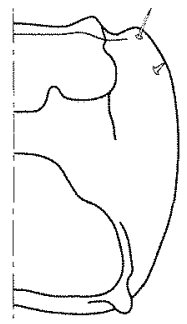

$19 \mathrm{a}$

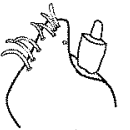

19
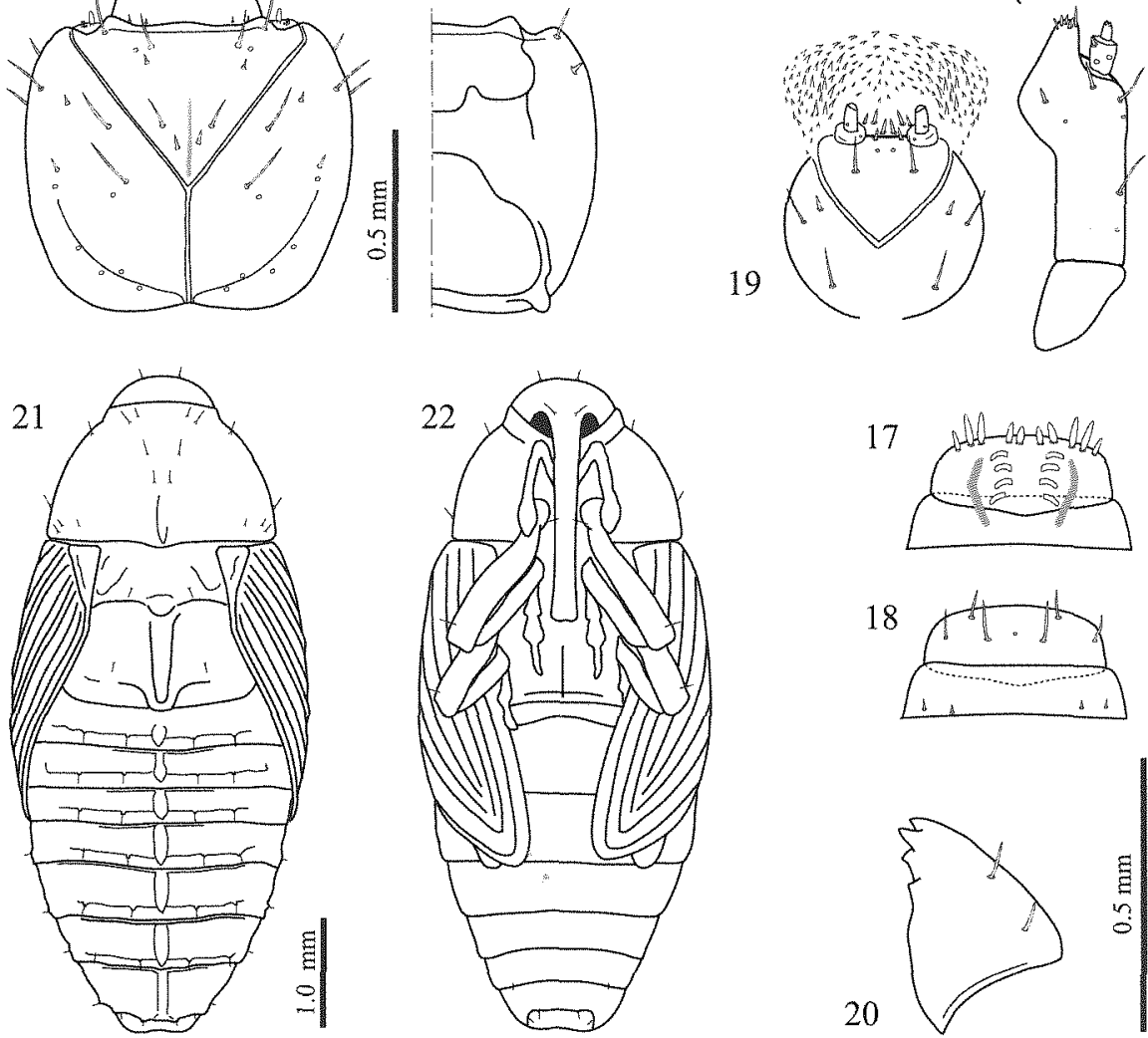

17

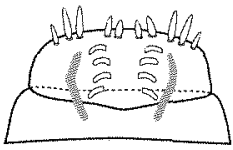

18

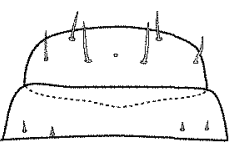

20

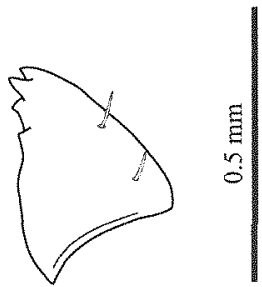

Figs. 13-22. Immature stages of Thanius biennis. 13, late-instar larva, lateral; 14, head capsule, frontal; 15, head capsule, ventral; 16, antenna; 17, clypeus and labrum; 18, epipharynx; 19, maxilla and labium, ventral (a, dorsal); 20, right mandible, dorsal; 21, pupa, dorsal; 22, pupa, ventral. 

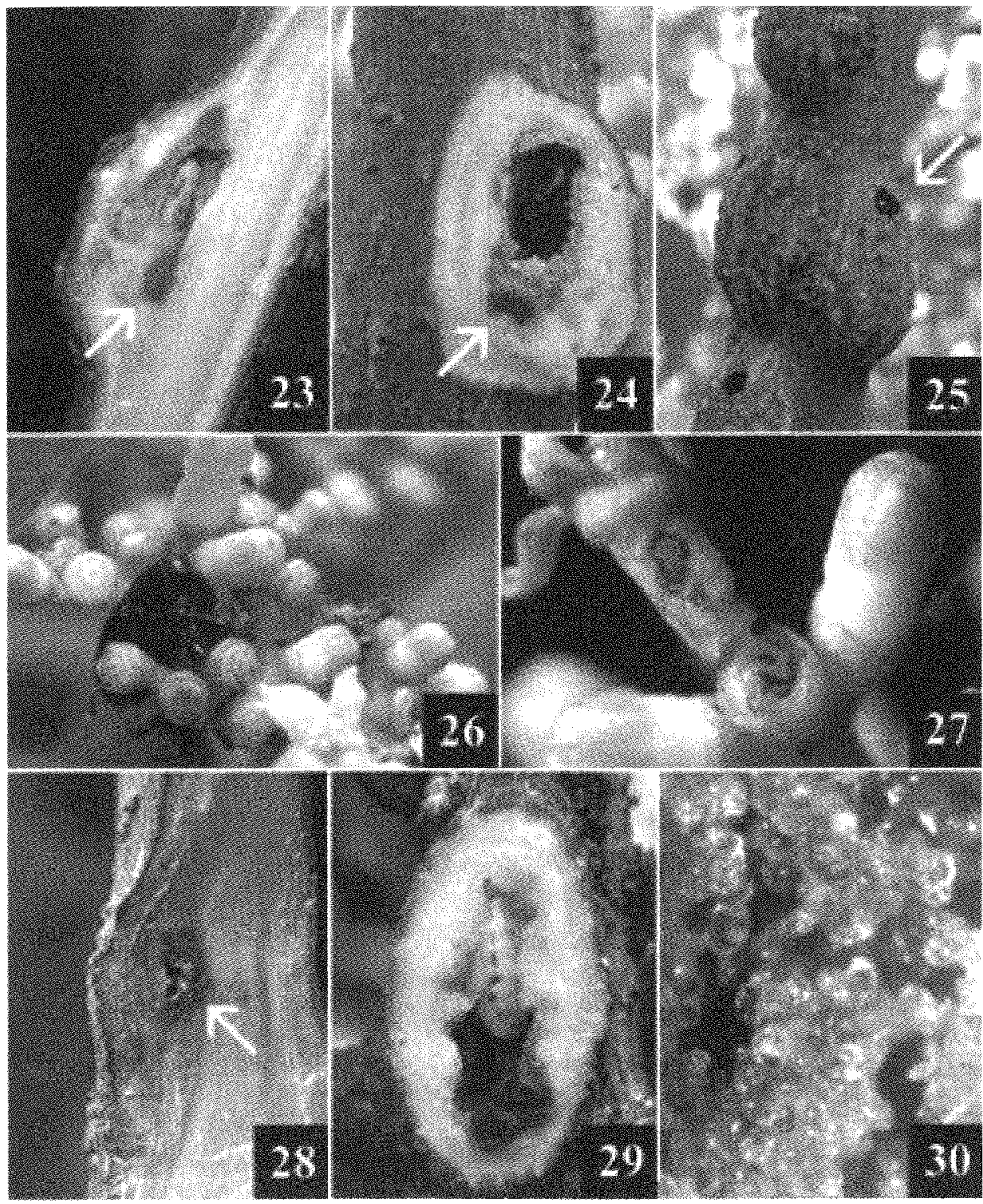

Figs. 23-30. Life history of Thanius biennis. 23, longitudinal section of one-year-old gall showing second-instar larva in situ; arrow indicates compacted fecal matter; 24 , dissected gall showing fully developed dormant adult; arrow indicates compacted fecal matter; 25 , recently abandoned mature galls with exit holes; arrow indicates weevil preparing exit; 26 , adult $T$. biennis on flower of $P$. marginata; 27 , feeding damage on flower of $P$. marginata made by adult $T$. biennis; 28 , longitudinal section of young gall with first-instar larva; 29 , dissected gall (top part removed) showing compacted fecal matter, chamber, nutritive tissue and third-instar larva in situ; 30, close-up of nutritive tissue (ca. $75 \mathrm{x}$ ). 


\section{References}

Bondar, G. 1949: Notas entomológicas da Bahía. XXI. - Rev. Entomol., Rio de J. 20 (1-3): 173-228.

CASEX, T. L. 1922: Studies in the Rhynchophorous subfamily Barinae of the Brazilian fauna. - Mem. Coleopt. 10: 1-520.

Champion, G. C. 1908: Biologia Centrali-Americana. Insecta. Coleoptera IV. 5: pp. 313-376.

Holdridge, L. R. 1967: Life zone ecology. Revised edition. - Tropical Science Center, San José, Costa Rica. -206 pp.

Hustache, A. 1951: Nouveaux Barinae Sud Américains. Deuxième partie - Barina. - Bol. Mus. Nac., Rio de J., Zool. (1949) 96: 1-78.

INBio 2004: On-line database of the Instituto Nacional de Biodiversidad Costa Rica. http://www.inbio. ac.cr/busqueda.phtml.

MaY, B. M. 1994: An introduction to the immature stages of Australian Curculionoidea. In: Zrmmerman, E. C. Australian Weevils Vol. II. - pp. 365-728.

MOBOT 2004: On-line database of the Missouri Botanical Garden. http://www.mobot.org/search.asp.

Strles, F. G. 1990: La Avifauna de la Universidad de Costa Rica y sus alrededores a través de veinte años (1968-1989). - Rev. Biol. Trop. 38: 361-381.

Authors' address:

Jens PREnA

Mozartstr. 24

18069 Rostock, Germany

baridinae@gmx.de

\author{
KenJi Nishida \\ Escuela de Biología, Universidad de Costa Rica \\ 2060 San José, Costa Rica \\ knishida@cariari.ucr.ac.cr
}

\section{Besprechungen}

Laclos, E. DE; Mouy, Ch.; Strenna, L. \& Agou, P.: Les Scolytes de Bourgogne (Coleoptera: Scolytidae - Platypodidae). - Autun: Societe d. Histoire Naturelle et des Amis du Museum, 2003. - 240 S., Fig. - ISBN 29507359-2-4.

Die Autoren gehen in einem sehr umfangreichen allgemeinen Teil auf grundlegende Dinge über Borkenkäfer ein, die es auch dem Praktiker ermöglichen, sich in die Borkenkäferkunde einzuarbeiten und die teilweise über die Bourgogne hinausgehen: z. B. Wie erkennt man einen Borkenkäfer?, Liste der Scolytidae und Platypodidae Frankreichs, Wie Leben die Scolytidae?, Wie sammelt man Scolytidae?, Hinweise zur Aufbewahrung in der Sammlung, äußere Morphologie der Imagines.

Sehr ausführlich wird auf die Historie der Erforschung, auf ihre Rolle in der Presse und auf ihre Bedeutung als Schädlinge eingegangen. In einem zweiten Teil werden speziell die Probleme der Bourgogne mit den Scolytidae behandelt und es wird auf die Arbeit der Forstverwaltung eingegangen. Es gibt hier eine Klimakarte und eine Karte der hauptsächlichen Forstregionen. Die Verbreitungskarten zu den Arten werden auf den Seiten 101-102 erläutert. Im speziellen Teil ab Seite 103 werden 33 Gattungen der Scolytidae und die Gattung Platypus der Platypodidae mit ihren Arten abgehandelt. In der Regel wird die Gattung auf einer Seite behandelt. Auch pro Art wird eine Seite verwendet, auf der eine Habitusabbildung und die Karte der Verbreitung in der Bourgogne enthalten sind. Bei umfangreicheren Gattungen gibt es Bestimmungstabellen, teilweise für die französischen Arten. Manchmal sind zur Unterscheidung ähnlicher Arten Detailabbildungen integriert. Gelegentlich werden Fraßbilder abgebildet. Den Autor bei Dendroctonus micans verbessere in Kugelann. Auf den Seiten 224-230 werden die Ergebnisse analysiert. In der Bourgogne wurden 79 Arten nachgewiesen; nach 1950 aber nur noch 77 Arten. Eine sechsseitige Bibliographie und ein Index zu den Gattungen und Arten beschließen den informativen Band. 